\title{
The Effect of Foot Orthosis Use in Reducing Pain in Patients with Plantar Fasciitis: A Meta-Analysis
}

\author{
Atika Febri Anggriani'), Agus Kristiyanto2), Setyo Sri Rahardjo3) \\ 1)Masters Program in Public Health, Universitas Sebelas Maret \\ 2)Faculty of Sports, Universitas Sebelas Maret \\ 3)Faculty of Medicine, Universitas Sebelas Maret
}

Background: Plantar fasciitis is an inflammatory problem that occurs in the foot area that causes pain. Its prevalence rates range from $4 \%$ to $7 \%$ in the elderly population, $8 \%$ in athletes and up to $25 \%$ in runners. One of the treatments used to reduce the degree of pain is the use of foot orthosis. A number of related articles stated that the use of foot orthosis can reduce the degree of pain in plantar fasciitis patients. The purpose of this study was to estimate the magnitude of the effect of using foot orthosis on pain reduction in plantar fasciitis patients by conducting a meta-analysis on the same number of articles.

Subjects and Method: The meta-analysis was carried out by systematically reviewing the same number of articles from PubMed, Science Direct, and Google Scholar. By using the search keywords "foot orthosis" OR "FO" AND "custom foot orthosis" AND "foot pain" AND "plantar fasciitis" AND "plantar fasciopathy" AND "effect foot orthosis for plantar fasciitis" AND "treatment for plantar fasciitis" A "randomized controlled trial". The intervention given was the use of a foot orthosis with a comparison without using a foot orthosis with the study subject of plantar fasciitis patients. The study outcome was pain reduction. The article used is a full text article with a randomized controlled trial design that reports the value of the effect size (mean and standard deviations). Articles were collected using the PRISMA flow chart and analyzed using the Review Manager 5.3 application with random effect models.

Results: A meta-analysis of 7 randomized controlled trial studies from Brazil, Virginia, Turkey, Germany, China, and Australia suggested that the use of foot orthosis was -0.54 times better at reducing pain in plantar fasciitis patients compared to those without foot orthosis $(\mathrm{ES}=-0.54 ; 95 \% \mathrm{CI}-1.11$ to $0.03 ; \mathrm{p}=0.06)$. Heterogeneity $\mathrm{I}^{2}=82 \%$.

Conclusion: Foot orthosis reduces pain in plantar fasciitis patients compared to those without foot orthosis

Keywords: Plantar fasciitis, pain, foot orthosis

\section{Correspondence:}

Atika Febri Anggriani, Masters Program in Public Health. Universitas Sebelas Maret, Jl. Ir. Sutami 36A, Surakarta 57126, Central Java, Indonesia. Email: atikaanggrianio7@gmail.com. Mobile : 085728794960

\section{Cite this as:}

Anggriani AF, Kristiyanto A, Rahardjo SS (2020). The Effect of Foot Orthosis Use in Reducing Pain in Patients with Plantar Fasciitis: A Meta-Analysis. J Epidemiol Public Health. 05(03): 309-319. https://doi.org/10.26911/jepublichealth.2020.05.03.05.

(c) (i) (2) Journal of Epidemiology and Public Healthis licensed under a Creative Commons Attribution-NonCommercial-ShareAlike 4.o International License.

\section{BACKGROUND}

One of the musculoskeletal problems that often occurs in the foot is plantar fasciitis (Rustanti and Wahyu, 2014). Plantar fasciitis is an inflammatory problem that occurs in the plantar fascia in the foot area.
The plantar fascia helps support the arch (arcus) in the foot.

$80 \%$ of these foot injuries are due to pain that occurs in the plantar area and 8$10 \%$ are due to injuries while running. Some of the causes of plantar fasciitis are 
obesity, degeneration, overuse, leg abnormalities such as flat foot/pes planus and high arch/pes cavus, sportsmen especially runners, and the tightness in the gastrocnemius or soleus muscles.

Plantar fasciitis can occur at all ages, but usually affects groups of people with an average age of 40-60 years old and can occur in active individuals or individuals who do not do much movement (Okur and Aydin, 2019). But in someone who has an abnormal foot, namely flat foot, it can occur at the age of less than 40 years old (Setyawan, 2016). The results of research conducted by Suzan stated that this plantar fasciitis accounts for $41.5 \%$ of problems in musculoskeletal cases in every tertiary care center in California, United States and has more than 600,000 outpatients each year (Goweda, 2015).

Some of the problems experienced by these plantar fasciitis patients are the emergence of pain (both silent pain, tenderness, and pain when moving) (Kuswardani et al., 2018). The pain occurs around the back of the heel. Pain in plantar fasciitis usually appears when waking up in the morning when the patient wants to place his/her foot on the floor for the first time, when standing for a long time, when walking long distances, when sitting too long, and will increase when walking.

Commonly used conservative methods to treat cases of plantar fasciitis include steroid injection, ultrasound therapy, laser therapy, extracorporeal shock wave therapy (ESWT), exercises and stretching therapy using the right footwear, and the use of orthoses (Okur and Aydin, 2019).

In the case of plantar fasciitis, orthotic prosthetics has an important role in improving the health status of the community because health is an important thing for society. In the treatment of plantar fasciitis, orthotic prostheses have a role in providing orthosis services in the form of foot orthosis/insole/footwear modifications/shoe modifications which have the aim of providing support to the plantar area of the foot so that it can reduce pain and can improve static balance in patients (Setyawan, 2016).

Many studies have shown that the use of foot orthoses of various types and designs can have an effect on reducing the degree of pain in plantar fasciitis patients.

One of them is a study conducted by Cozta, 2019 which focuses at the effect of insole on flip-flops in people with plantar fasciopathy showing a reduction in the degree of pain with $(\mathrm{MD}=-1.82 ; 95 \% \mathrm{CI}=-$ 3.3 to $-0.3 ; \mathrm{p}=0.016)$. This study supported the authors to carry out systematic reviews and meta-analyzes involving orthotic treatment with the use of foot orthoses in reducing the pain of plantar fasciitis patients.

\section{SUBJECTS AND METHOD}

\section{Study Design}

This study is a systematic study and metaanalysis. The articles used in this study were obtained from several databases including PubMed, Science Direct, and Google Scholar. The keywords were "foot orthosis" OR "FO" AND "custom foot orthosis" AND "foot pain" AND "plantar fasciitis" AND“plantar fasciopathy" AND "effect foot orthosis for plantar fasciitis" AND "treatment for plantar fasciitis" "randomized controlled trial".

\section{Inclusion Criteria}

The articles included in this study were full paper articles with a randomized controlled trial (RCT). The intervention given was the use of a foot orthosis with a comparison without foot orthosis with the research subject being plantar fasciitis patients of all ages. The study outcome was pain reduc- 
tion, with the articles of which the study was conducted around the world.

\section{Exclusion Criteria}

Articles published in this study were articles published in languages other than English and articles published under 2000.

4. Operational Definition of Variables The article search was carried out by considering the eligibility criteria defined using the PICO model. The population in this study was plantar fasciitis patients at all ages, intervention in the form of use of foot orthosis, comparison, namely not using foot orthosis and outcome in the form of pain reduction.

Pain is an unpleasant sensory and emotional experience due to the damage done to the tissue, either actual or potential or described in the form of damage to the part itself. Instrument: VAS scale with a continue measurement scale.
Foot orthoses (FO) is a type of orthosis that is used to correct, immobilize, compensate, relieve deformities that occur in the foot joint. Instruments: medical records with a categorical measuring scale.

\section{Data Analysis}

Data processing was carried out by the Review Manager (RevMan 5.3) by calculating the standardized mean difference to determine the research model that was combined and formed the final metaanalysis result.

\section{RESULTS}

The process of searching for articles by conducting database searches with PRISMA flow diagrams can be seen in Figure 1.

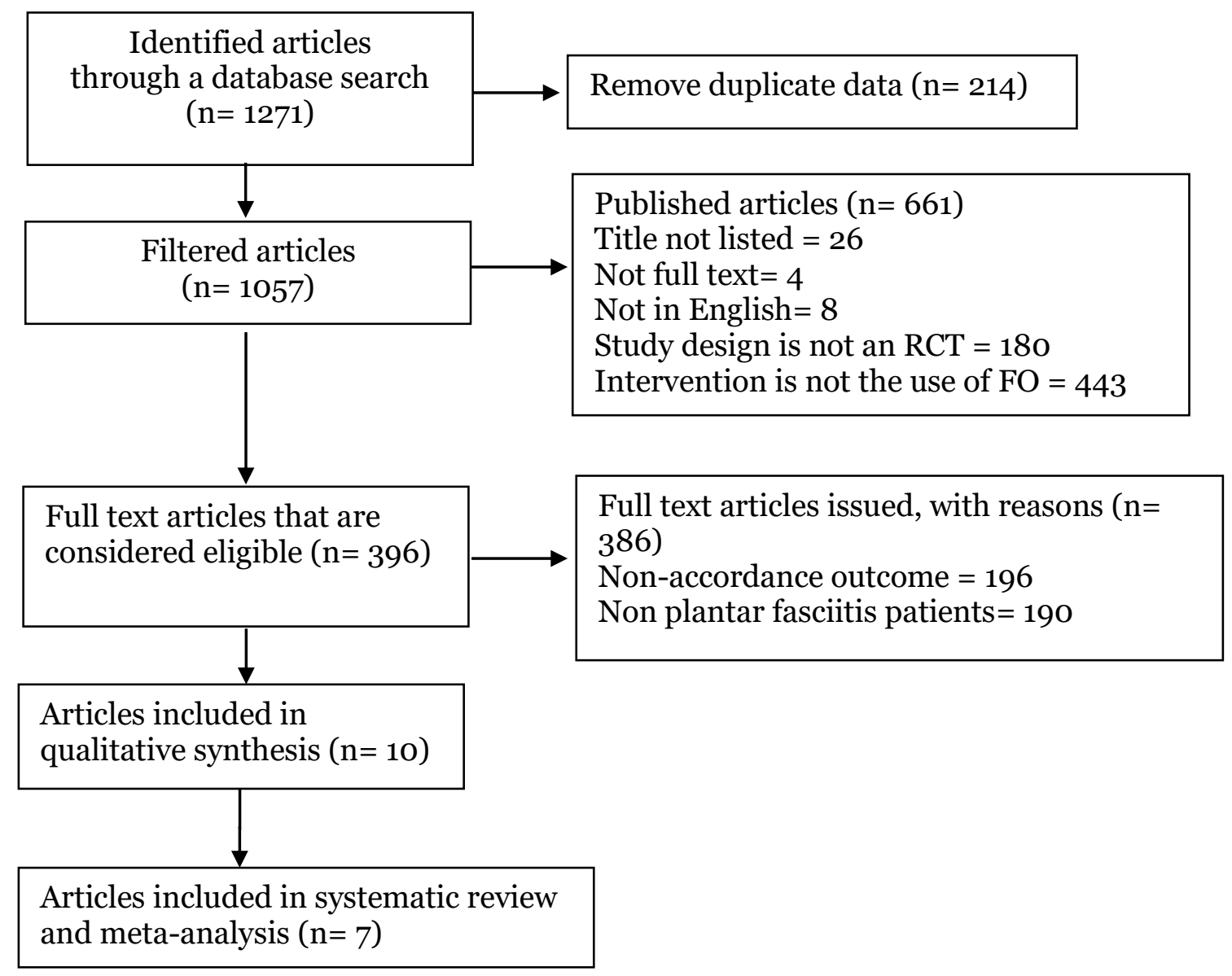


Anggriani et al./ The Effect of Foot Orthosis Use in Reducing Pain

Figure 1. flow chart diagram 
Anggriani et al./ The Effect of Foot Orthosis Use in Reducing Pain

Table 1. Assessment of Study Quality

\begin{tabular}{|c|c|c|c|c|c|c|c|c|c|c|c|c|c|c|c|c|c|c|c|c|c|}
\hline \multirow{2}{*}{$\begin{array}{l}\text { Checklist } \\
\text { questions }\end{array}$} & \multicolumn{3}{|c|}{$\begin{array}{l}\text { Costa et al., } \\
(2019)\end{array}$} & \multicolumn{3}{|c|}{$\begin{array}{c}\text { Oliveira et al., } \\
\text { (2015) }\end{array}$} & \multicolumn{3}{|c|}{$\begin{array}{l}\text { Lunen et al., } \\
\text { (2011) }\end{array}$} & \multicolumn{3}{|c|}{ Yucel et al., (2013) } & \multicolumn{3}{|c|}{$\begin{array}{c}\text { Walther et al., } \\
\text { (2013) }\end{array}$} & \multicolumn{3}{|c|}{ Fong et al., (2012) } & \multicolumn{3}{|c|}{$\begin{array}{c}\begin{array}{c}\text { Bishop et al., } \\
(2018)\end{array} \\
\end{array}$} \\
\hline & Yes & $\begin{array}{l}\text { Not } \\
\text { explai } \\
\text { ned }\end{array}$ & No & Yes & $\begin{array}{l}\text { Not } \\
\text { explai } \\
\text { ned }\end{array}$ & No & Yes & $\begin{array}{c}\text { Not } \\
\text { explai } \\
\text { ned }\end{array}$ & No & Yes & $\begin{array}{l}\text { Not } \\
\text { explai } \\
\text { ned }\end{array}$ & No & Yes & $\begin{array}{l}\text { Not } \\
\text { explai } \\
\text { ned }\end{array}$ & No & Yes & $\begin{array}{l}\text { Not } \\
\text { explai } \\
\text { ned }\end{array}$ & No & Yes & $\begin{array}{l}\text { Not } \\
\text { explai } \\
\text { ned }\end{array}$ & No \\
\hline $\begin{array}{l}\text { Does this study } \\
\text { address a clear } \\
\text { research focus? }\end{array}$ & $\sqrt{ }$ & & & $\sqrt{ }$ & & & $\sqrt{ }$ & & & $\sqrt{ }$ & & & $\sqrt{ }$ & & & $\sqrt{ }$ & & & $\sqrt{ }$ & & \\
\hline $\begin{array}{l}\text { Is the RCT } \\
\text { research method } \\
\text { suitable for } \\
\text { answering } \\
\text { research } \\
\text { questions? }\end{array}$ & $\sqrt{ }$ & & & $\sqrt{ }$ & & & $\sqrt{ }$ & & & $\sqrt{ }$ & & & $\sqrt{ }$ & & & $\sqrt{ }$ & & & $\sqrt{ }$ & & \\
\hline $\begin{array}{l}\text { Are there enough } \\
\text { subjects in the } \\
\text { study to establish } \\
\text { that the findings } \\
\text { were not made by } \\
\text { chance? }\end{array}$ & $\sqrt{ }$ & & & $\sqrt{ }$ & & & $\sqrt{ }$ & & & $\sqrt{ }$ & & & $\sqrt{ }$ & & & $\sqrt{ }$ & & & $\sqrt{ }$ & & \\
\hline $\begin{array}{l}\text { Are subjects } \\
\text { randomly } \\
\text { allocated to the } \\
\text { experimental and } \\
\text { control groups? If } \\
\text { not, could this be } \\
\text { biased? }\end{array}$ & $\sqrt{ }$ & & & $\sqrt{ }$ & & & $\sqrt{ }$ & & & $\sqrt{ }$ & & & $\sqrt{ }$ & & & $\sqrt{ }$ & & & $\sqrt{ }$ & & \\
\hline $\begin{array}{l}\text { Is inclusion/ } \\
\text { exclusion criteria } \\
\text { are used? }\end{array}$ & $\sqrt{ }$ & & & $\sqrt{ }$ & & & $\sqrt{ }$ & & & $\sqrt{ }$ & & & $\sqrt{ }$ & & & $\sqrt{ }$ & & & $\sqrt{ }$ & & \\
\hline Are the two & $\sqrt{ }$ & & & $\sqrt{ }$ & & & $\sqrt{ }$ & & & $\sqrt{ }$ & & & $\sqrt{ }$ & & & $\sqrt{ }$ & & & $\sqrt{ }$ & & \\
\hline
\end{tabular}




\begin{tabular}{|c|c|c|c|c|c|c|c|c|c|c|c|c|c|c|c|c|c|c|c|c|c|}
\hline \multirow{2}{*}{$\begin{array}{l}\text { Checklist } \\
\text { questions }\end{array}$} & \multicolumn{3}{|c|}{$\begin{array}{c}\text { Costa et al., } \\
(2019)\end{array}$} & \multicolumn{3}{|c|}{$\begin{array}{c}\text { Oliveira et al., } \\
\text { (2015) }\end{array}$} & \multicolumn{3}{|c|}{$\begin{array}{c}\text { Lunen et al., } \\
\text { (2011) }\end{array}$} & \multicolumn{3}{|c|}{ Yucel et al., (2013) } & \multicolumn{3}{|c|}{$\begin{array}{c}\text { Walther et al., } \\
(2013)\end{array}$} & \multicolumn{3}{|c|}{ Fong et al., (2012) } & \multicolumn{3}{|c|}{$\begin{array}{c}\text { Bishop et al., } \\
\text { (2018) }\end{array}$} \\
\hline & Yes & $\begin{array}{c}\text { Not } \\
\text { explai } \\
\text { ned }\end{array}$ & No & Yes & $\begin{array}{l}\text { Not } \\
\text { explai } \\
\text { ned }\end{array}$ & No & Yes & $\begin{array}{c}\text { Not } \\
\text { explai } \\
\text { ned }\end{array}$ & No & Yes & $\begin{array}{c}\text { Not } \\
\text { explai } \\
\text { ned }\end{array}$ & No & Yes & $\begin{array}{c}\text { Not } \\
\text { explai } \\
\text { ned }\end{array}$ & No & Yes & $\begin{array}{c}\text { Not } \\
\text { explai } \\
\text { ned }\end{array}$ & No & Yes & $\begin{array}{c}\text { Not } \\
\text { explai } \\
\text { ned }\end{array}$ & No \\
\hline $\begin{array}{l}\text { groups compa- } \\
\text { rable at study } \\
\text { entry? }\end{array}$ & & & & & & & & & & & & & & & & & & & & & \\
\hline $\begin{array}{l}\text { Are objective and } \\
\text { unbiased out- } \\
\text { come criteria } \\
\text { used? }\end{array}$ & $\checkmark$ & & & $\sqrt{ }$ & & & $\sqrt{ }$ & & & $\sqrt{ }$ & & & $\sqrt{ }$ & & & $\sqrt{ }$ & & & $\sqrt{ }$ & & \\
\hline $\begin{array}{l}\text { Are objective and } \\
\text { validated } \\
\text { measurement } \\
\text { methods used to } \\
\text { measure the } \\
\text { results? If not, } \\
\text { are the results } \\
\text { scored by some- } \\
\text { one who does not } \\
\text { know the group } \\
\text { assignment (i.e. is } \\
\text { the grading } \\
\text { blended)? }\end{array}$ & $\sqrt{ }$ & & & $\sqrt{ }$ & & & $\sqrt{ }$ & & & $\sqrt{ }$ & & & $\sqrt{ }$ & & & $\sqrt{ }$ & & & $\sqrt{ }$ & & \\
\hline $\begin{array}{l}\text { Is the effect size } \\
\text { practically } \\
\text { relevant? }\end{array}$ & $\sqrt{ }$ & & & $\sqrt{ }$ & & & $\sqrt{ }$ & & & $\sqrt{ }$ & & & $\sqrt{ }$ & & & $\sqrt{ }$ & & & $\sqrt{ }$ & & \\
\hline $\begin{array}{l}\text { How precise is } \\
\text { the estimated } \\
\text { effect? Is there a } \\
\text { confidence }\end{array}$ & $\sqrt{ }$ & & & $\sqrt{ }$ & & & $\sqrt{ }$ & & & $\sqrt{ }$ & & & $\sqrt{ }$ & & & $\sqrt{ }$ & & & $\sqrt{ }$ & & \\
\hline
\end{tabular}




\begin{tabular}{|c|c|c|c|c|c|c|c|c|c|c|c|c|c|c|c|c|c|c|c|c|c|}
\hline \multirow{2}{*}{$\begin{array}{l}\text { Checklist } \\
\text { questions }\end{array}$} & \multicolumn{3}{|c|}{$\begin{array}{l}\text { Costa et al., } \\
(2019)\end{array}$} & \multicolumn{3}{|c|}{$\begin{array}{l}\text { Oliveira et al., } \\
(\text { (2015) }\end{array}$} & \multicolumn{3}{|c|}{$\begin{array}{l}\text { Lunen et al., } \\
\text { (2011) }\end{array}$} & \multicolumn{3}{|c|}{ Yucel et al., (2013) } & \multicolumn{3}{|c|}{$\begin{array}{c}\text { Walther et al., } \\
(2013)\end{array}$} & \multicolumn{3}{|c|}{ Fong et al., (2012) } & \multicolumn{3}{|c|}{$\begin{array}{c}\text { Bishop et al., } \\
\text { (2018) }\end{array}$} \\
\hline & Yes & $\begin{array}{l}\text { Not } \\
\text { explai } \\
\text { ned }\end{array}$ & No & Yes & $\begin{array}{l}\text { Not } \\
\text { explai } \\
\text { ned }\end{array}$ & No & Yes & $\begin{array}{l}\text { Not } \\
\text { explai } \\
\text { ned }\end{array}$ & No & Yes & $\begin{array}{l}\text { Not } \\
\text { explai } \\
\text { ned }\end{array}$ & No & Yes & $\begin{array}{c}\text { Not } \\
\text { explai } \\
\text { ned }\end{array}$ & No & Yes & $\begin{array}{c}\text { Not } \\
\text { explai } \\
\text { ned }\end{array}$ & No & Yes & $\begin{array}{c}\text { Not } \\
\text { explai } \\
\text { ned }\end{array}$ & No \\
\hline interval? & & & & & & & & & & & & & & & & & & & & & \\
\hline $\begin{array}{l}\text { Could there be } \\
\text { confounding } \\
\text { factors that have } \\
\text { not been taken } \\
\text { into account? }\end{array}$ & $\sqrt{ }$ & & & $\sqrt{ }$ & & & $\sqrt{ }$ & & & $\sqrt{ }$ & & & $\sqrt{ }$ & & & $\sqrt{ }$ & & & $\sqrt{ }$ & & \\
\hline $\begin{array}{l}\text { Are the results } \\
\text { applicable to your } \\
\text { study? }\end{array}$ & $\sqrt{ }$ & & & $\sqrt{ }$ & & & $\sqrt{ }$ & & & $\sqrt{ }$ & & & $\sqrt{ }$ & & & $\sqrt{ }$ & & & $\sqrt{ }$ & & \\
\hline
\end{tabular}

Table 2. Summary Source Articles

The 7 articles showed that there was an effect of using foot orthosis on reducing the degree of pain in plantar fasciitis patients

\begin{tabular}{|c|c|c|c|c|c|c|c|}
\hline $\begin{array}{l}\text { Author } \\
\text { (Year) }\end{array}$ & Country & $\begin{array}{c}\text { Study } \\
\text { Design }\end{array}$ & Sample & $\mathbf{P}$ & $\mathbf{I}$ & C & $\mathbf{O}$ \\
\hline $\begin{array}{l}\text { Costa et al., } \\
(2019)\end{array}$ & Brazil & $\begin{array}{l}\text { Randomized } \\
\text { Controlled } \\
\text { Trial }\end{array}$ & $\begin{array}{l}\text { Foot orthosis: } \\
34 \\
\text { Non foot } \\
\text { orthosis : } 32\end{array}$ & $\begin{array}{l}\text { Plantar fasciitis patients } \\
\text { with an average age in the } \\
\text { intervention group were } \\
47.4 \text { years old and in the } \\
\text { control group were } 47.8 \\
\text { years old. }\end{array}$ & $\begin{array}{l}\text { To examine the effect of using } \\
\text { foot orthosis on pain *, foot } \\
\text { function, and functional capa- } \\
\text { city in plantar fasciitis } \\
\text { patients. }\end{array}$ & $\begin{array}{l}\text { Not examine the effect of } \\
\text { using foot orthosis on pain, } \\
\text { foot function, and functio- } \\
\text { nal capacity in plantar } \\
\text { fasciitis patients. }\end{array}$ & $\begin{array}{l}\text { Reduction in } \\
\text { degree of pain }\end{array}$ \\
\hline $\begin{array}{l}\text { Oliveira et } \\
\text { al., (2015) }\end{array}$ & Brazil & $\begin{array}{l}\text { Randomized } \\
\text { Controlled } \\
\text { Trial }\end{array}$ & $\begin{array}{l}\text { Foot orthosis : } \\
37 \\
\text { Non foot } \\
\text { orthosis: } 37\end{array}$ & $\begin{array}{l}\text { Plantar fasciitis patients } \\
\text { with an average age in the } \\
\text { intervention group were } 48 \\
\text { years old and in the control } \\
\text { group were } 53 \text { years old }\end{array}$ & $\begin{array}{l}\text { Examine the effect of using } \\
\text { foot orthosis on pain *, quality } \\
\text { of life, foot function, and } \\
\text { plantar pressure in plantar } \\
\text { fasciitis patients. }\end{array}$ & $\begin{array}{l}\text { Did not examine the effect } \\
\text { of using foot orthosis on } \\
\text { pain, quality of life, foot } \\
\text { function, and plantar } \\
\text { pressure in plantar fasciitis } \\
\text { patients. }\end{array}$ & $\begin{array}{l}\text { Reduction in } \\
\text { degree of pain }\end{array}$ \\
\hline
\end{tabular}




\begin{tabular}{|c|c|c|c|c|c|c|c|}
\hline $\begin{array}{l}\text { Author } \\
\text { (Year) }\end{array}$ & Country & $\begin{array}{l}\text { Study } \\
\text { Design }\end{array}$ & Sample & $\mathbf{P}$ & I & $\mathbf{C}$ & $\mathbf{O}$ \\
\hline $\begin{array}{l}\text { Lunen et al., } \\
\text { (2011) }\end{array}$ & Virginia & $\begin{array}{l}\text { Randomized } \\
\text { Controlled } \\
\text { Trial }\end{array}$ & $\begin{array}{l}\text { Foot orthosis: } \\
17 \\
\text { Non foot } \\
\text { orthosis: } 17\end{array}$ & $\begin{array}{l}\text { Patients with unilateral and } \\
\text { bilateral plantar fasciitis }\end{array}$ & $\begin{array}{l}\text { Examine the effect of using } \\
\text { foot orthosis on pain *, peak } \\
\text { plantar pressure, and mean } \\
\text { plantar pressure in plantar } \\
\text { fasciitis patients. }\end{array}$ & $\begin{array}{l}\text { Not examine the effect of } \\
\text { using foot orthosis on pain, } \\
\text { peak plantar pressure, and } \\
\text { mean plantar pressure in } \\
\text { plantar fasciitis patients. }\end{array}$ & $\begin{array}{l}\text { Reduction in } \\
\text { degree of pain }\end{array}$ \\
\hline $\begin{array}{l}\text { Yucel et al., } \\
(2013)\end{array}$ & Turkey & $\begin{array}{l}\text { Randomized } \\
\text { Controlled } \\
\text { Trial. }\end{array}$ & $\begin{array}{l}\text { Foot orthosis : } \\
20 \\
\text { Non foot } \\
\text { orthosis : } 20\end{array}$ & $\begin{array}{l}\text { Chronic unilateral plantar } \\
\text { fasciitis patient }\end{array}$ & $\begin{array}{l}\text { To examine the effect of us } \\
\text { foot orthosis on the manag } \\
\text { ment of plantar fasciitis which } \\
\text { includes pain *, thickness of } \\
\text { the plantar fascia in plantar } \\
\text { fasciitis patients. }\end{array}$ & $\begin{array}{l}\text { Not examine the effect of } \\
\text { asing foot orthosis on the } \\
\text { management of plantar } \\
\text { fasciitis which includes } \\
\text { pain, thickness of the } \\
\text { plantar fascia in plantar } \\
\text { fasciitis patients. }\end{array}$ & $\begin{array}{l}314 \text { tion in } \\
\text { degree of pain }\end{array}$ \\
\hline $\begin{array}{l}\text { Walther et } \\
\text { al., (2013) }\end{array}$ & Germany & $\begin{array}{l}\text { Randomized } \\
\text { Controlled } \\
\text { Trial. }\end{array}$ & $\begin{array}{l}\text { Foot orthosis : } \\
10 \\
\text { Non foot } \\
\text { orthosis : } 10\end{array}$ & $\begin{array}{l}\text { Plantar fasciitis patients } \\
\text { with an average age of } 51.6 \\
\text { to } 53.9 \text { years old. }\end{array}$ & $\begin{array}{l}\text { Evaluating the effectiveness of } \\
\text { foot orthosis in plantar fasciitis } \\
\text { treatment which includes pain } \\
\text { *, walking distance, and } \\
\text { sucjective comfort of plantar } \\
\text { fasciitis patients. }\end{array}$ & $\begin{array}{l}\text { Not evaluating the effec- } \\
\text { tiveness of foot orthosis in } \\
\text { plantar fasciitis treatment } \\
\text { which includes pain, walk- } \\
\text { ing distance, and sucjective } \\
\text { comfort for plantar fasciitis } \\
\text { patients. }\end{array}$ & $\begin{array}{l}\text { Reduction in } \\
\text { degree of pain }\end{array}$ \\
\hline $\begin{array}{l}\text { Fong et al., } \\
\text { (2012) }\end{array}$ & China & $\begin{array}{l}\text { Randomized } \\
\text { Controlled } \\
\text { Trial. }\end{array}$ & $\begin{array}{l}\text { Foot orthosis : } \\
15 \\
\text { Non foot } \\
\text { orthosis : } 15\end{array}$ & $\begin{array}{l}\text { Unilateral plantar fasciitis } \\
\text { patients aged 40-64 years } \\
\text { old }\end{array}$ & $\begin{array}{l}\text { Evaluating the use of foot } \\
\text { orthosis on pain levels } * \text { and } \\
\text { dynamic plantar pressure in } \\
\text { plantar fasciitis patients. }\end{array}$ & $\begin{array}{l}\text { Did not evaluate the use of } \\
\text { foot orthosis on pain levels } \\
\text { and dynamic plantar } \\
\text { pressure in plantar fasciitis } \\
\text { patients. }\end{array}$ & $\begin{array}{l}\text { Reduction in } \\
\text { degree of pain }\end{array}$ \\
\hline $\begin{array}{l}\text { Bishop et al., } \\
\text { (2018) }\end{array}$ & Australia & $\begin{array}{l}\text { Randomized } \\
\text { Controlled } \\
\text { Trial }\end{array}$ & $\begin{array}{l}\text { Foot orthosis : } \\
20 \\
\text { Non foot } \\
\text { orthosis : } 20\end{array}$ & $\begin{array}{l}\text { Patients with unilateral } \\
\text { plantar fasciitis had an } \\
\text { average age in the inter- } \\
\text { vention group were } 44.5 \\
\text { years old and in the control } \\
\text { group were } 44.7 \text { years old. }\end{array}$ & $\begin{array}{l}\text { To examine the effect of using } \\
\text { foot orthosis on pain * and } \\
\text { plantarfascia thickness in } \\
\text { plantar fasciitis patients. }\end{array}$ & $\begin{array}{l}\text { Not examine the effect of } \\
\text { using foot orthosis on pain } \\
\text { and plantarfascia thickness } \\
\text { in plantar fasciitis patients. }\end{array}$ & $\begin{array}{l}\text { Reduction in } \\
\text { degree of pain }\end{array}$ \\
\hline
\end{tabular}

* Variables included in the meta-analysis 
Anggriani et al./ The Effect of Foot Orthosis Use in Reducing Pain

a. Forest plot

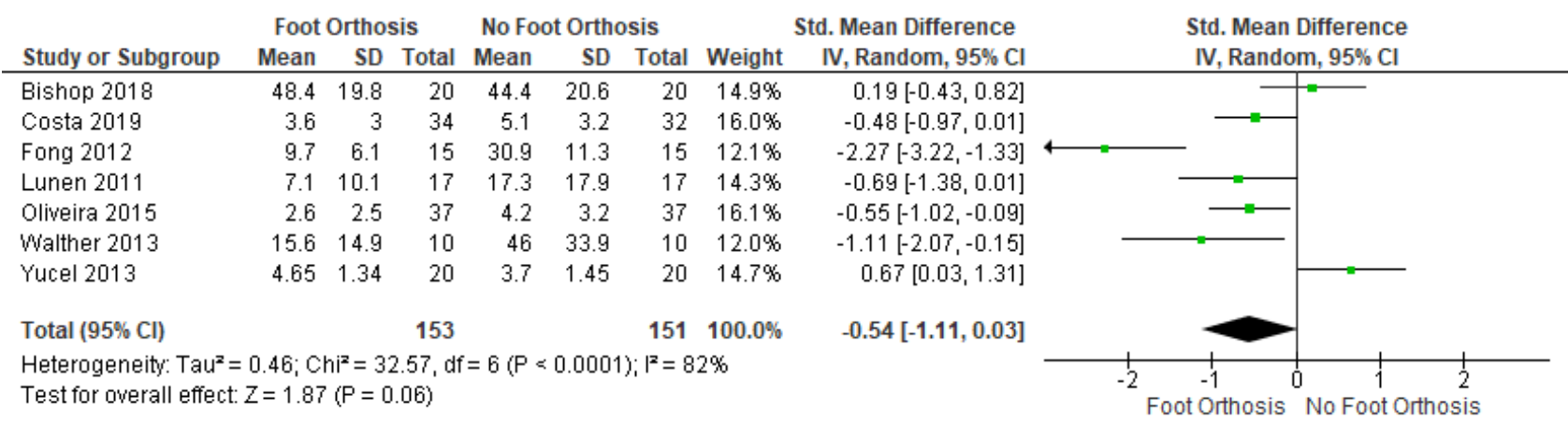

\section{Figure 2. Forest plot of the effect of using foot orthosis to reduce the degree of pain}

\section{b. Funnel plot}

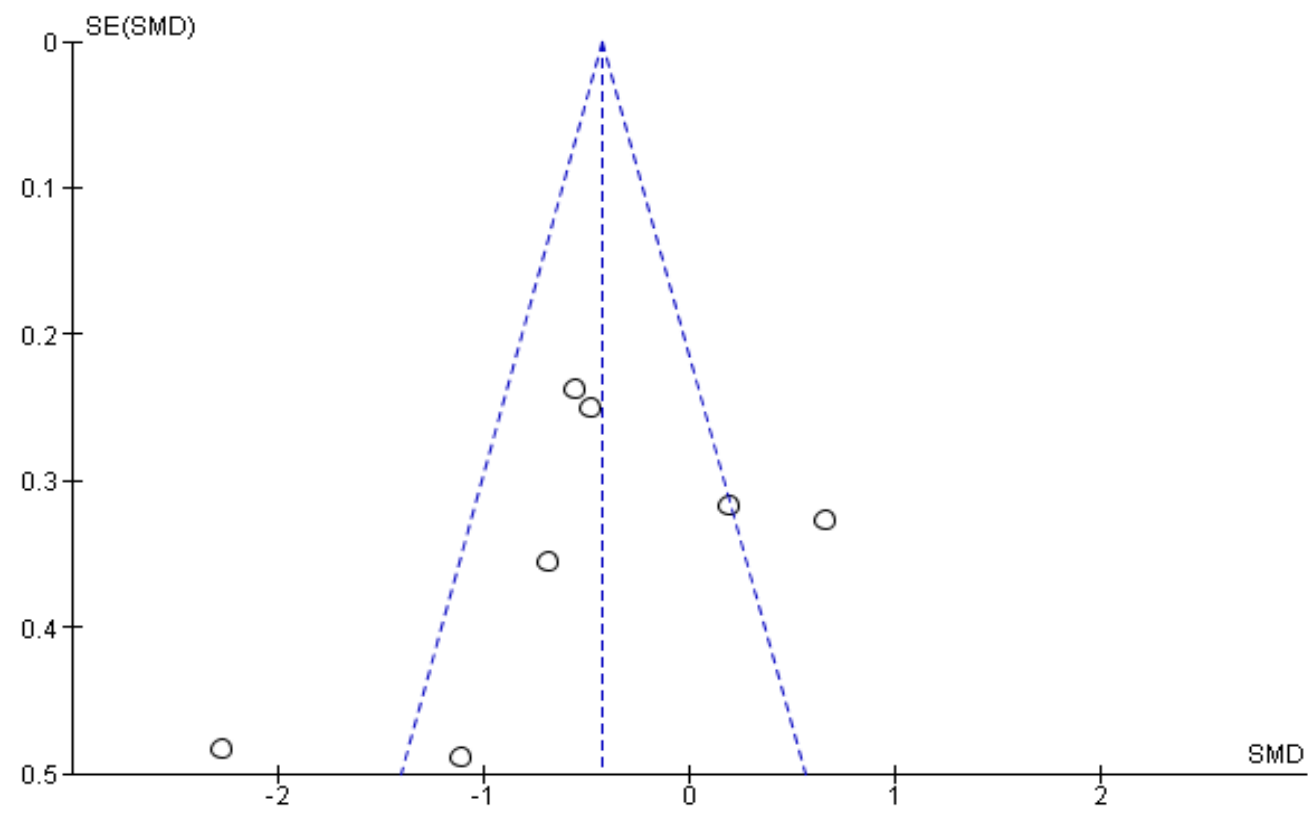

Figure 3. Funnel plot of the effect of using foot orthosis to reduce the degree of pain in plantar fasciitis patients

Based on the results of the forest plot (Figure 2), it showed that the use of a -0.54 foot orthosis reduced the degree of pain in plantar fasciitis patients compared to without using foot orthosis and it was statistically insignificant $(\mathrm{p}=0.06)$. The heterogeneity of the study data showed $\mathrm{I}^{2}=82 \%$ so that the distribution of the data was heterogeneous (random effect model). The funnel plot (Figure 3) showed a publication bias which was indicated by asymmetry of the right and left plots where 2 plots were on the right and 5 plots were on the left. The plot on the left of the graph has a standard error between 0.2 and 0.5 and the plot on the right has a standard error between 0.3 and 0.4. Bias also occurred from an imbalance between the distance between the studies on the right and left of the funnel plot. 


\section{DISCUSSION}

Plantar fasciitis is a condition of abnormalities in the foot joint that can affect all ages, but usually affects groups of people aged 40-60 years old and can occur in active individuals or individuals who do not do much movement (Okur and Aydin, 2019). But for someone who has an abnormal foot, which is flat foot, it can occur at the age of less than 40 years old (Setyawan, 2016). In general, the prevalence rate ranges from $4 \%$ to $7 \%$ in the older population, $8 \%$ in athletes and up to $25 \%$ in runners (Whittaker et al., 2017).

The results of research conducted by Suzan stated that this fasciitis platar contributes $41.5 \%$ of problems in musculoskeletal cases in every tertiary care center in California, United States. Approximately $10 \%$ of the US population complains of the incidence of pain in plantar fasciitis cases and results in one million professional visits for plantar fasciitis treatment each year. In the United States, plantar fasciitis accounts for more than 600,000 outpatients each year (Goweda, 2015). Based on data obtained from monthly reports at the medical rehabilitation clinic of the Bhakti Wira Tamtama Army Hospital, Semarang, Central Java, in 2017 there were 67 patients who experienced cases of plantar fasciitis from January to December 2018.

This systematic and meta-analysis study raised the theme of the effect of using foot orthosis on reducing the degree of pain in plantar fasciitis patients. This study discussed data about pain which was considered important because of the effects that were caused if no follow-up treatment was given. Pain in plantar fasciitis occurs due to stretching or overloading of the longitudinal arch or due to loss of the longitudinal arch in the foot. The purpose of using a foot orthosis in this case was to provide support to the plantar area of the foot so that it can reduce pain and increase the static balance in the patient (Setyawan, 2016).

Systematic review and meta-analysis in this study were carried out with the aim of increasing the generalizability of the findings and obtaining convincing conclusions from the results of various similar studies regarding the use of a foot orthosis was -0.54 times better to reduce the degree of pain than without using a foot orthosis ( $E S=-0.54 ; 95 \%$ CI -1.11 to 0.03 ; $p=0.06$ ). The results showed a reduction in pain. The heterogeneity of the study data showed $\mathrm{I}^{2}=$ $82 \%$, which indicated the distribution of heterogeneous data, so that the analysis uses a random effect model. Therefore, from the results of meta-analysis, it showed that the use of foot orthosis has an effect on reducing the degree of pain in plantar fasciitis patients.

The results of the data analysis that have been carried out were in line with research conducted by Oliveira et al., (2015) which states that the use of foot orthosis can be used to reduce pain when walking and can increase walking distance in someone who has plantar fasciitis.

In principle, the plantaris fascia will stretch out if there is pressure on the body because the plantaris fascia serves as a shock absorber. When there is inflammation in the plantar fascia, pain will appear when there is pressure on the body. Foot orthosis can reduce pain because the tool works with its mechanism, namely that the heel pad will reduce or reduce the compressive force on the heel. Then the pressure on the heel will be distributed on the arch support to the forefoot. This equalization of pressure on the feet will relax the plantar facia. Biomechanically, the medial wedge will hold the weight of the foot, especially the midfoot, so that the plantar facia 
attachment does not experience a stretching that causes pain. In addition, the medial wedge also functions to prevent pronation of the feet which causes the plantar fascia to stretch out (stretching). Therefore, the arcus area needs to be supported to reduce the body's compressive force so as to reduce the stretching power of the plantar fascia (Setyawan, 2016). Foot orthosis is used to help relieve tension and inflammation associated with inflammatory plantar fasciitis and degeneration of the thick bands of tissue that support the soles of the feet. This orthosis is made of a sponge and plastic material, which aims to provide support to the plantar area of the foot in order to reduce pain.

It can be concluded that the use of foot orthosis can reduce the degree of pain in plantar fasciitis patients, but it is not statistically significant.

\section{AUTHOR CONTRIBUTION}

Atika Febri Anggriani is the main researcher who selected a topic, explored and collected research data. Agus Kristiyanto and Setyo Sri Rahardjo had a role in analyzing data and reviewing study documents.

\section{CONFLICT OF INTEREST}

There was no conflict of interest.

\section{FUNDING AND SPONSORSHIP}

This study used private funds from the main researcher

\section{ACKNOWLEDGEMENT}

We are very thankful to the database providers of PubMed, Science Direct, and Google Scholar

\section{REFERENCE}

Bishop C, Thewlis D, Hillier S (2018). Custom foot orthoses improve first-step pain in individuals with unilateral plantar fasciopathy: a pragmatic randomised controlled trial. BMC Musculoskelet. Disord, 19(222): 1-11. DOI: https://doi.org/10.1186/s12891018-2131-6

Cozta ARA, Silva HJA, Mendes AAFT, Silva RS, Lins CAA, Souza MC (2019). Effects of insoles adapted in flip-flop sandals in people with plantar fasciopathy: a randomized, double-blind clinical, controlled study. Clin. Rehabil, 1-11. DOI: https://doi.org/10.1177/0269215519893104

Fong DTP, Pang KY, Chung MML, Hung ASL, Chan KM (2012). Evaluation of combined prescription of rocker sole shoes and custom-made foot orthoses for the treatment of plantar fasciitis. Clin Biomech, 27 (1072-1077). DOI: https://dx.doi.org/10.1016/j.clinbiom ech.2012.08.003

Goweda, Reda A, dkk (2015). Prevalence and risk factors of plantar fasciitis among patients with heel pain attending primary health care centers of makkah kingdom of saudi arabia. High Inst. Public Health, 2 45(2): 7175. https://dx.doi.org/10.21608/jhiph.2015.20247.

Kuswardani, Amanati S, Yudhanto NU (2018). Pengaruh infrared, ultrasound dan terapi latihan pada faciitis plantaris (The effect of infrared, ultrasound and exercise therapy on plantar faciitis). J Physiother, 2 (1): 78-87.

Lunen BV, Cortes N, Andrus T, Wlker M, Pasquale M, Onate J (2011). Immediate effects of a heel pain orthosis and an augmented low-dye taping on plantar pressures and pain in subjects with plantar fasciitis. Clin $\mathrm{J}$ sport medicine, 21: (474-479). https://doi.org/10.1097/JSM.obo13e3182340199 
Murti B (2018). Prinsip dan metode riset epidemiologi. Edisi V. (Epidemiological research principles and methods. Edition V) Bintang fajar Offset Colomadu, Karanganyar, Jawa Tengah.

Okur SC, Aydin A (2019). Comparison of extracorporeal shock wafe therapy with custom foot orthotics in plantar fasciitis treatment: A prospective randomized one-year follow-up study. $\mathrm{J}$ Musculoskeletal Neuronal Interact, 19(2): 178-186.

Oliveira HAV, Jones A, Moreira E, Jennings F, Natour J (2015). Effectiveness of Total Contact Insoles in Patients with Plantar Fasciitis. J Rheumatol, 42(5): 870-878. https://doi.org/10.3899/jrheum.140429.

Rustanti M, Wahyu SD (2014). Pengaruh penggunaan medial arch support terhadap penurunan derajat nyeri pada kasus plantar fasciitis (The effect of using medial arch support on reducing the degree of pain in cases of plantar fasciitis). J. Phys. Ther. Sci., 3(2): 106-214.

Setyawan, D (2016). Pengaruh penggunaan medial arch support terhadap pengurangan derajat nyeri, keseimbangan statis dan activity of daily living pada pasien plantar faciitis (The effect of using medial arch support on the reduction of pain degrees, static balance and activity of daily living in plantar faciitis patients). J Phys Ther Sci. 1(2): 75-152.

Walther M, Kratschmer B, Verschl J, Volkering C, Altenberger S, Kriegelstein S, Hilgers M (2013). Effect of different orthotic concepts as first line treatment of plantar fasciitis. Foot Ankle Surg, 19: 103-107. DOI: https://www.researchgate.net/deref/http\%3A\%2F\%2Fdx.doi.org\%2F10.1016\%2 Fj.fas.2012.12.008

Whittaker GA, Munteanu SE, Menz HB, Tan JM, Rabusin CL, Landorf KBF (2017). Orthoses for plantar heel pain: a systematic review and meta-analysis. Br. J. Sports med, 52: 322-328. http://dx.doi.org/10.1136/bjsports2016-097355

Yucel U, Kucuksen S, Cingos HT, Anliacik E, Ozbek O, Salli A, Ugurlu H (2013). Full-length silicone insoles versus ultrasound-guided corticosteroid injection in the management of plantar fasciitis: A randomized clinical trial. Prosthet Orthot Int, 37: 471. Doi: 10.1177/0309364613478328. 